\title{
Formulation and In Vitro Evaluation of Telmisartan Nanoparticles Prepared by Emulsion-Solvent Evaporation Technique
}

\author{
Emülsiyon-Çözücü Buharlaştırma Tekniği ile Hazırlanan Telmisartan \\ Nanopartiküllerinin Formülasyonu ve in Vitro Değerlendirilmesi
}

\author{
(D) Naile ÖZTÜRK1, (D) Aslı KARA2, (D) Imran VURAL3* \\ 1Inönü University Faculty of Pharmacy, Department of Pharmaceutical Technology, Malatya, Turkey \\ 2 Hitit University Sungurlu Vocational High School, Department of Medical Services and Techniques, Çorum, Turkey \\ 3Hacettepe University Faculty of Pharmacy, Department of Pharmaceutical Technology, Ankara, Turkey
}

\section{ABSTRACT}

Objectives: Telmisartan (TLM) is an antihypertensive drug that has been shown to have antiproliferative effects on cancer cells. It has low solubility and suboptimal oral bioavailability. To investigate the potential anticancer effect of TLM on breast cancer cells, poly (D, L-lactide) (PLA) nanoparticles were formulated with the benefit of improving its solubility.

Materials and Methods: TLM-loaded PLA nanoparticles were prepared by emulsion solvent evaporation. The effects of sonication time and polymer:drug ratio on nanoparticle size and drug encapsulation were investigated. TLM-loaded nanoparticles were tested against MCF-7 and MDAMB-231 breast cancer cell lines for antiproliferative effects.

Results: Nanoparticles with mean particle size $272 \mathrm{~nm}$ and $79 \%$ encapsulation efficiency were obtained. Sustained release TLM nanoparticles (40\% in 24 h) decreased cell viability to $45 \%$ for MCF-7 cells at 72 h, even at the lowest TLM concentration, indicating better anticancer efficiency than TLM solution.

Conclusion: TLM nanoparticles could be potential anticancer agents for breast cancer and deserve further studies.

Key words: Telmisartan, nanoparticles, anticancer effect, drug repositioning

öz

Amaç: Telmisartan (TLM), kanser hücreleri üzerinde antiproliferatif etkisi olduğu gösterilmiş antihipertansif bir ilaçtır. Düşük çözünürlüğe, suboptimal oral biyoyararlanıma sahiptir. TLM'nin meme kanseri hücreleri üzerindeki potansiyel antikanser etkisini araştırmak için, TLM'nin çözünürlüğünü iyileștiren poli (D, L-laktid) PLA nanopartikülleri formüle edilmiștir.

Gereç ve Yöntemler: TLM yüklü PLA nanopartikülleri emülsiyon hazırlama-çözücü buharlaştırma yöntemiyle hazırlanmıştır. Sonikasyon süresi ve polimer: ilaç oranının nanopartikül büyüklüğü ve ilaç enkapsülasyonu üzerindeki etkisi araştırılmıştır. TLM yüklü nanopartiküllerin, antiproliferatif etkileri MCF-7 ve MDA-MB-231 meme kanseri hücre hatları kullanılarak test edilmiştir.

Bulgular: Ortalama partikül büyüklüğü 272 nm ve \%79 enkapsülasyon etkinliğine sahip nanopartiküller elde edilmiştir. Sürekli salım gösteren TLM nanopartikülleri (24 saatte \%40) MCF-7 hücrelerinde, TLM çözeltisinden daha iyi antikanser aktivite göstererek, en düșük TLM konsantrasyonunda bile hücre canlılığını 72 saatte $\% 45$ 'e düșürmüștür.

Sonuç: TLM nanopartiküllerinin, meme kanseri için potansiyel antikanser ajanlar olabileceği ve daha ileri çalışmalarda araştırılmaya değer olduğu sonucuna varılmıştır.

Anahtar kelimeler: Telmisartan, nanopartiküller, antikanser etki, ilaç yeniden konumlandırma

*Correspondence: E-mail: +90 312305 12 41, Phone: imranvural23@gmail.com ORCID-ID: orcid.org/0000-0002-1627-3834

Received: 17.07.2019, Accepted: 30.07.2019

๑Turk J Pharm Sci, Published by Galenos Publishing House. 


\section{INTRODUCTION}

Drugs are developed by a long and costly development process. However, finding new uses for existing drugs is an alternative strategy that shortens the time to market and lowers the cost for developers. By employing this strategy new anticancer agents could be discovered and more accessible treatments could be presented to patients. Angiotensin II receptor blockers (ARBs) are an example for old drugs that are investigated for potential new activities. Telmisartan (TLM), which is an ARB used for the treatment of hypertension, has been investigated in this context and antiproliferative activity of TLM against various cancer cells such as lung adenocarcinoma cells, urological cancer cells, and endometrial cancer cells has been discovered.-3 It was reported that TLM has an antiproliferative effect on leukemia cell lines and ex vivo peripheral blood monocytes, and TLM causes autophagy and apoptosis by caspase activation. ${ }^{4}$ Besides being an ARB, TLM is also described as a peroxisome proliferator-activated receptor (PPAR)-gamma activator and in some studies its antitumor activity is linked to PPAR-gamma activation.1-3 Intraperitoneal administration of TLM to human endometrial tumor-bearing nude mice showed that treatment with TLM inhibited tumor growth significantly. ${ }^{2}$ In a transgenic rat model for prostate cancer, TLM was administered orally in drinking water (2 or $10 \mathrm{mg} / \mathrm{kg} /$ day) for 12 weeks and it was found that TLM suppressed prostate cancer by activation of caspases, inactivation of p38 MAPK, and downregulation of the androgen receptor. ${ }^{5}$

Considering the potential anticancer application of TLM, it is also important to design an optimal formulation for effective therapy. TLM has poor aqueous solubility $(0.6 \mu \mathrm{g} / \mathrm{mL})$ and its solubility is $\mathrm{pH}$-dependent. ${ }^{6}$ According to the Biopharmaceutics Classification System (BCS), it is classified as a BCS II drug ${ }^{7}$ (low solubility, high permeability) and its oral bioavailability is 43\%. ${ }^{8}$ To improve its oral bioavailability, nanoparticle systems are one of the methods that are being investigated. ${ }^{7,9}$ Moreover, for effective cancer therapy, accumulation of anticancer agent at the tumor site with minimum distribution in healthy tissues is a major goal. For TLM, its side-effect profile is reported as comparable to that of a placebo; ${ }^{10}$ however, using nanoparticles (NPS) to achieve TLM accumulation at the tumor site can enhance the interaction of TLM with cancer cells, which leads to improved cancer therapy.

In the present work TLM was encapsulated with NPS that were formed by biodegradable poly ( $D$, L-lactide) (PLA) polymer. The NPS were prepared by emulsion-solvent evaporation and studies were carried out to optimize particle size. The anticancer effect of TLM-loaded NPS was investigated against MCF-7 and MDA-MB-231 breast cancer cells.

\section{MATERIALS AND METHODS}

\section{Materials}

TLM was a kind gift from Nobel Pharmaceutical Industry and Trade Inc. Co., Turkey. Dichloromethane, dimethyl sulfoxide (DMSO), PLA (average Mw 75,000-120,000), and poly (vinyl alcohol) (PVA) (average mol wt 30,000-70,000) were purchased from Sigma-Aldrich Co., USA. MCF-7 and MDA-MB-231 cell lines were obtained from the American Type Culture Collection. Fetal bovine serum (FBS) and penicillin/streptomycin, Dulbecco's Modified Eagle Medium (DMEM), and 3-(4,5-dimethylthiazol2-yl)-2,5-diphenyltetrazolium bromide (MTT) were purchased from Biochrom (Germany). All other reagents were analytical grade.

\section{Preparation of nanoparticles}

NPS were prepared by a modified emulsion solvent evaporation method." PLA was dissolved in $1 \mathrm{~mL}$ of dichloromethane and $10 \mathrm{~mL}$ of PVA aqueous solution $(0.3 \% \mathrm{w} / \mathrm{v})$ was added to it. The mixture was vortexed for $1 \mathrm{~min}$ and then immediately was sonicated using a probe-type sonicator (Bandelin Sonopuls HD2200). After sonication the dichloromethane was evaporated by a rotary evaporator (IKA RV10). Then the NPS were centrifuged at $15.000 \mathrm{rpm}$ for $15 \mathrm{~min}(23.656 \mathrm{x} \mathrm{g}$, Hermle Z323K). The precipitated NPS were suspended in ultrapure water and centrifuged twice more for the washing steps. For TLM-loaded NPS (TLM-NP) the same procedure was performed with addition of TLM to dichloromethane. The effect of sonication time on blank and TLM-loaded NP size (polymer:drug ratio, 25:1 mg/mg) was investigated using different sonication times (5, 10, 20 min). After determining the optimal sonication time for obtaining the smallest NPS, two more polymer:drug ratios (25:2, 25:0.5, mg:mg) were studied to obtain TLM-NP and to observe the effect of drug amount on nanoparticle size and encapsulation efficiency (EE).

\section{Characterization studies}

\section{Particle size and zeta potential measurements}

The particle size, polydispersity index (PDI), and zeta potential values of blank and TLM-NP were measured by dynamic light scattering method using a Malvern Zeta Sizer Nano Series ZS instrument (UK). Measurements were performed for both freshly prepared and lyophilized NPS. The initial experiments showed that NPS lyophilized without any additive were not dispersible. Thus they were freeze-dried using 5\% trehalose as cryoprotectant to prevent aggregation.

\section{Encapsulation efficiency and drug loading capacity}

Suspended NPS were frozen at $-20{ }^{\circ} \mathrm{C}$ for $16 \mathrm{~h}$ and then were lyophilized for $48 \mathrm{~h}$ (Labconco, Freezone 4.5). The lyophilized NPS were dissolved in DMSO and were analyzed by ultravioletvisible (UV-Vis) spectrophotometry at $309 \mathrm{~nm}$ to determine the encapsulated TLM amount. Spectrums in DMSO were used to show insignificant absorbance of PLA polymer at $309 \mathrm{~nm}$. The concentration range of the calibration curve was $1-20 \mu \mathrm{g} / \mathrm{mL}$. The regression equation was $\mathrm{y}=0.048 \mathrm{x}-0.006$ (standard error (SE) of slope was $8 \times 10^{-5}$, SE of intercept was $2 \times 10^{-3}$, and $R^{2}$ was 1) and the limit of detection (LOD) was $0.3 \mu \mathrm{g} / \mathrm{mL}$ and limit of quantification (LOQ) was $0.8 \mu \mathrm{g} / \mathrm{mL}$.

EE and drug loading capacity (DLC) were calculated using equations 1 and 2, respectively.

$E E=m a s s$ of the drug in NPS/mass of drug used initially Equation 1 
DLC=mass of the drug in NPS/total mass of the NPS Equation 2

In vitro drug release

In vitro drug release experiments were carried out using the dialysis membrane method in a shaking water bath. NPS were dispersed in phosphate buffered saline (PBS) containing 0.5\% $(\mathrm{w} / \mathrm{v})$ sodium lauryl sulfate (SLS) and $1 \mathrm{~mL}$ of this suspension was placed into a dialysis bag (molecular weight cutoff 8000 Da). The dialysis bag was placed in $50 \mathrm{~mL}$ of $0.5 \% \mathrm{SLS}$ containing PBS and at specific time points $1 \mathrm{~mL}$ of release medium was withdrawn to determine the amount of TLM released. At each time point, $1 \mathrm{~mL}$ of fresh medium was added to the release medium after sampling. In addition, coarse TLM powder was dispersed in PBS containing 0.5\% SLS and TLM dissolution was determined under the same conditions as for NPS.

Samples were analyzed by UV-Vis spectrophotometry using a calibration curve obtained from TLM solutions in $0.5 \%$ SLS containing PBS at $300 \mathrm{~nm}$. The calibration curve was obtained in the concentration range of $0.5-10 \mu \mathrm{g} / \mathrm{mL}$. The regression equation was $y=0.048 x-0.002$ (SE of slope was 0.0002 , SE of intercept was 0.0008 , and $R^{2}$ was 1 ) and the LOD and LOQ were $0.1 \mu \mathrm{g} / \mathrm{mL}$ and $0.4 \mu \mathrm{g} / \mathrm{mL}$, respectively.

\section{Scanning electron microscopy (SEM)}

NP morphology was observed with SEM. A NP suspension (10 $\mu \mathrm{L}$ ) was placed on aluminum foil and was air dried. Then the foil was placed onto an SEM stub and was coated with gold/ palladium using a BAL-TEC SCD 050 (Liechtenstein). The coated sample was visualized with a LEO-EVO 40 (UK) SEM unit.

\section{Cell culture studies}

MCF-7 and MDA-MB-231 cell lines were grown in DMEM containing penicillin (IU/mL), streptomycin $(50 \mu \mathrm{g} / \mathrm{mL})$, and $10 \%$ FBS and were maintained in a humidified atmosphere of $95 \%$ air and $5 \% \mathrm{CO}_{2}$ at $37{ }^{\circ} \mathrm{C}$. Cells were seeded at a density 5000 cells/well in $100 \mu \mathrm{L}$ of complete culture medium in a 96-well plate. After overnight incubation, the medium was removed from the wells and serial dilutions of TLM solution (in complete medium containing 1\% DMSO), blank-NP (B-NP), and TLM-NP in complete culture medium were applied to the cells. As the control, cells were treated with complete medium alone and complete medium containing $1 \%$ DMSO. Following 24,48 , and $72 \mathrm{~h}$ of incubation $25 \mu \mathrm{L}$ of MTT solution ( $5 \mathrm{mg} / \mathrm{mL}$ in PBS) was added to the wells. After $4 \mathrm{~h}$ of incubation the medium was removed from the wells and $200 \mu \mathrm{L}$ of DMSO was added to them to dissolve the formazan crystals. The optical densities of plates were measured using a microplate reader (Molecular Devices, USA) at $570 \mathrm{~nm}$. Cell viability was calculated as the percentage of control cells.

\section{Statistics analysis}

The results were presented as the mean and standard deviation/ SE. Statistical analysis was performed by GraphPad Prism using One and Two-Way ANOVA and $p<0.05$ was considered statistically significant.

\section{RESULTS}

\section{Particle size and zeta potential of nanoparticles}

NPS were prepared by emulsion solvent evaporation and their particle size and zeta potential were measured directly after preparation. In addition, to investigate the effect of freezedrying on particle size, the particle size of lyophilized NPS (freeze-dried with 5\% trehalose) was measured. Firstly, three different sonication times were used to investigate the effect of sonication time on the size and EE of NPS. Particle size and zeta potential data of the freshly prepared and lyophilized B-NP, TLM-NP with different sonication times are given in Table 1. Particle size and zeta potential data of the blank and freshly prepared and lyophilized B-NP, TLM-NP with different sonication times are given in Table 1. Zeta potential values were negative and between -10 and $-20 \mathrm{mV}$ for all formulations and NP size was between 218 and $238 \mathrm{~nm}$ for blank formulations and between 273 and $333 \mathrm{~nm}$ for the TLM-NP formulations. The smallest NP size was obtained with 10 min sonication; therefore, formulations of different polymer:drug ratios were prepared by performing $10 \mathrm{~min}$ sonication. After the freezedrying process nanoparticle size was decreased for both blank and TLM formulations, which indicates the stabilizing effect of trehalose. Zeta potential values of freeze-dried formulations were slightly lower than those of freshly prepared NPS and were between -7.0 and $-9.5 \mathrm{mV}$.

Particle size and zeta potential values of TLM-NP, which were prepared using different drug amounts, are given in

Table 1. Effect of sonication time on the particle size, polydispersity index, and zeta potential of freshly prepared and freeze-dried formulations ( $n=3$, mean \pm standard deviation)

\begin{tabular}{|c|c|c|c|c|c|c|c|}
\hline \multirow{2}{*}{ Sonication time (minute) } & \multicolumn{4}{|l|}{ B-NP } & \multicolumn{3}{|l|}{ TLM-NP } \\
\hline & Particle & $(n m)$ & PDI & Zeta potential $(\mathrm{mV})$ & Particle size (nm) & PDI & Zeta potential $(\mathrm{mV})$ \\
\hline 5 & \multirow{3}{*}{ Fresh } & $237.8 \pm 1.1$ & $0.1 \pm 0.0$ & $-15.2 \pm 1.3$ & $332.6 \pm 3.8$ & $0.3 \pm 0.0$ & $-10.5 \pm 2.1$ \\
\hline 10 & & $218.1 \pm 3.6$ & $0.1 \pm 0.0$ & $-18.8 \pm 0.5$ & $272.6 \pm 1.6$ & $0.2 \pm 0.0$ & $-15.0 \pm 2.6$ \\
\hline 20 & & $223.6 \pm 1.5$ & $0.1 \pm 0.0$ & $-15.7 \pm 2.0$ & $302.2 \pm 3.1$ & $0.3 \pm 0.0$ & $-15.7 \pm 0.4$ \\
\hline 5 & \multirow{3}{*}{$\begin{array}{l}\text { Freeze- } \\
\text { dried }\end{array}$} & $210.1 \pm 1.7$ & $0.1 \pm 0.0$ & $-7.0 \pm 0.2$ & $227.1 \pm 8.2$ & $0.2 \pm 0.0$ & $-7.9 \pm 0.2$ \\
\hline 10 & & $205.9 \pm 3.9$ & $0.1 \pm 0.0$ & $-9.5 \pm 0.4$ & $215.5 \pm 3.7$ & $0.1 \pm 0.0$ & $-8.1 \pm 0.2$ \\
\hline 20 & & $212.4 \pm 1.6$ & $0.1 \pm 0.0$ & $-8.5 \pm 0.5$ & $286.7 \pm 9.1$ & $0.2 \pm 0.0$ & $-7.4 \pm 0.2$ \\
\hline
\end{tabular}

PDI: Polydispersity index, TLM-NP: Telmisartan-loaded nanoparticles, B-NP: Blank-nanoparticles 
Table 2. Particle size of the formulations with 25:2 and 25:0.5 polymer:drug ratios was smaller than that of the formulation with 25:1 polymer:drug ratio for freshly prepared NPS. Freezedried formulations showed different behavior in terms of particle size. While for the formulations of 25:1 and 25:0.5 polymer:drug ratios particle size decreased with freeze-drying, for the formulation of $25: 2$ polymer:drug ratio the opposite was true. The heterogeneity of the particle size distribution of this formulation (25:2 polymer:drug ratio) is thought to be the reason behind the further aggregation during lyophilization.

\section{Encapsulation efficiency and drug loading capacity}

Three different polymer:drug ratios were studied to investigate the effect on NP EE. The EE and DLC of TLM-NP are presented in Table 3. The highest drug loading was obtained with the formulation of 25:1 polymer:drug ratio.

\section{In vitro drug release}

The NP formulation with the highest EE (polymer:drug ratio, 25:1, mg:mg) was selected for in vitro drug release experiments. The release profiles of TLM-NP and TLM in PBS with $0.5 \%$ SLS are given in Figure 1. It was clear from the TLM release profile (around $40 \%$ release at the end of $24 \mathrm{~h}$ ) that the NPS showed controlled release. Moreover, the TLM NPS displayed higher dissolution, compared to $17.2 \%$ release of TLM in $24 \mathrm{~h}$.

\section{Scanning electron microscopy}

Freshly prepared NP suspension (polymer:drug ratio, 25:1, $\mathrm{mg}: \mathrm{mg}$ ) was placed on aluminum foil and after drying in

\begin{tabular}{|c|c|c|c|}
\hline $\begin{array}{l}\text { Polymer:drug ratio } \\
\text { (mg/mg) }\end{array}$ & $\begin{array}{l}\text { Particle size } \\
(\mathrm{nm})\end{array}$ & PDI & $\begin{array}{l}\text { Zeta potential } \\
(\mathrm{mV})\end{array}$ \\
\hline 25:0.5 & $233.8 \pm 2.0$ & $0.2 \pm 0.0$ & $-15.2 \pm 0.4$ \\
\hline $\begin{array}{l}\text { Fresh } \\
\text { NP }\end{array}$ & $272.6 \pm 1.6$ & $0.2 \pm 0.0$ & $-15.0 \pm 2.6$ \\
\hline $25: 2$ & $226.2 \pm 9.4$ & $0.3 \pm 0.1$ & $-11.1 \pm 0.5$ \\
\hline 25:0.5 & $228.0 \pm 4.6$ & $0.2 \pm 0.0$ & $-12.2 \pm 0.2$ \\
\hline Freeze- & $215.5 \pm 3.7$ & $0.1 \pm 0.0$ & $-8.1 \pm 0.2$ \\
\hline $25: 2$ & $267.8 \pm 3.3$ & $0.3 \pm 0.0$ & $-7.5 \pm 0.2$ \\
\hline
\end{tabular}

PDI: Polydispersity index, NP: Nanoparticles

Table 3. Encapsulation efficiency and drug loading capacity of telmisartan-loaded nanoparticles ( $n=3$, mean \pm standard deviation)

\begin{tabular}{llll}
$\begin{array}{l}\text { Polymer:drug ratio (mg/ } \\
\mathrm{mg})\end{array}$ & $\begin{array}{l}\text { Sonication time } \\
(\mathrm{min})\end{array}$ & $\mathrm{EE} \mathrm{( \% )}$ & DLC (\%) \\
\hline $25: 0.5$ & 10 & $40.0 \pm 1.2$ & $1.1 \pm 0.1$ \\
\hline $25: 1$ & 5 & $79.1 \pm 3.5$ & $5.4 \pm 0.1$ \\
\hline $25: 1$ & 10 & $37.7 \pm 0.2$ & $1.7 \pm 0.1$ \\
\hline $25: 1$ & 20 & $97.4 \pm 0.9$ & $4.8 \pm 0.1$ \\
\hline $25: 2$ & 10 & $60.3 \pm 2.1$ & $5.3 \pm 0.3$ \\
\hline
\end{tabular}

EE: Encapsulation efficiency, DLC: Drug loading capacity atmospheric conditions the NPS were visualized by SEM as presented in Figure 2.

\section{Cell culture studies}

MCF-7 and MDA-MB-231 cells were used as model cell lines to investigate whether there is an antiproliferative effect of TLM and TLM-NP on breast cancer cells. The cell viability results for 24, 48, and $72 \mathrm{~h}$ incubation periods are given in Figures 3-5, respectively.

For MCF-7 cells, B-NP did not reduce cell viability below $80 \%$ at $24 \mathrm{~h}$ incubation period and at 48 and $72 \mathrm{~h}$ the highest concentration resulted in $73 \%$ and $67 \%$ cell viability, respectively (Figures $3 \mathrm{a}, 4 \mathrm{a}$, and $5 \mathrm{a}$ ). TLM solution reduced cell viability to $75 \%$ at 24 h, to $61 \%$ at 48 h, and to $60 \%$ at 72 h (Figures 3a, 4a, and 5a). However, there was not a dramatic difference between the viability results of different concentrations of TLM treatments at each time period. The TLM-NP formulation decreased cell viability in a concentration-dependent manner and at the highest TLM concentration viability decreased to $45 \%$ at $24 \mathrm{~h}$ and $72 \mathrm{~h}$ (Figures $3 \mathrm{a}$ and $5 \mathrm{a}$ ). As the incubation time increased lower TLM concentrations caused lower cell viability results.

For MDA-MB-231 cells, B-NP did not reduce cell viability below $76 \%$ even at $72 \mathrm{~h}$ incubation (Figures $3 \mathrm{~b}, 4 \mathrm{~b}$, and $5 \mathrm{~b}$ ). TLM solution reduced cell viability in a dose-dependent manner;

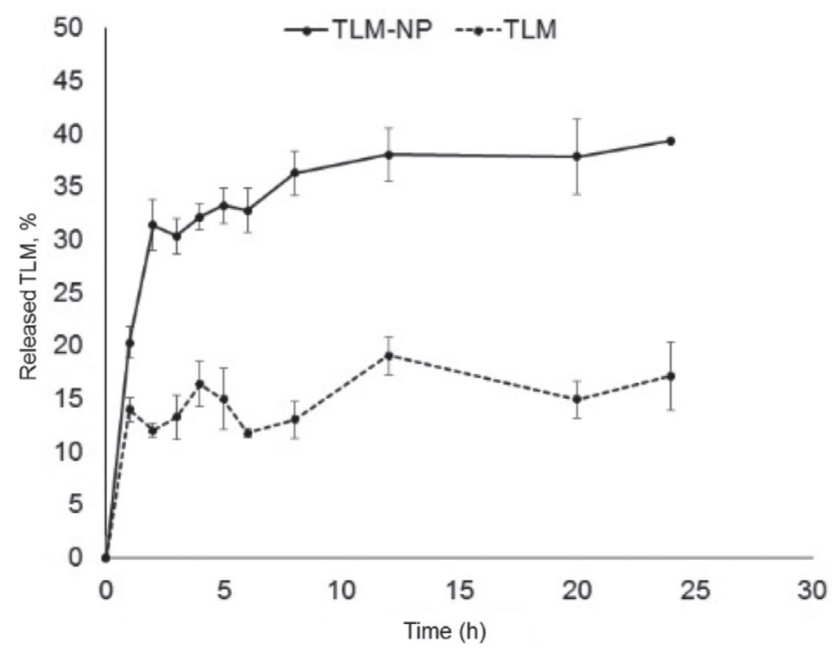

Figure 1. In vitro release profile of TLM-loaded nanoparticles and TLM ( $n=3$, mean \pm SE)

TLM-NP: Telmisartan-loaded nanoparticles, SE: Standard error

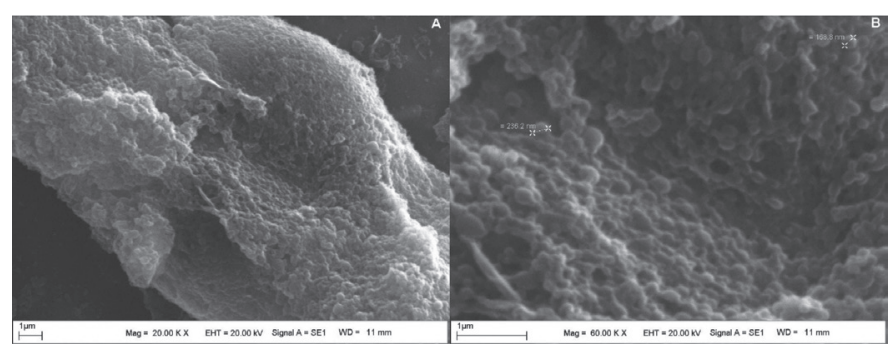

Figure 2. SEM images of TLM-loaded nanoparticles at A: $20 \mathrm{~K}$ magnification B: 60K magnification

SEM: Scanning electron microscopy, TLM: Telmisartan 


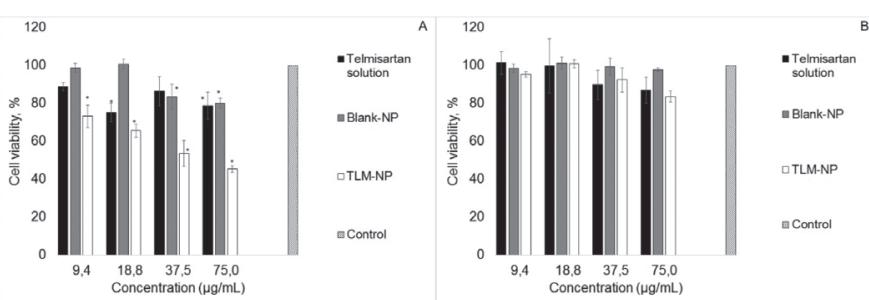

Figure 3. Cell viability of formulations after $24 \mathrm{~h}$ incubation. A: MCF-7 cells, B: MDA-MB-231 cells $(n=3$, mean \pm SE). *Indicates significantly different from control $(p<0.05)$

SE: Standard error, TLM-NP: Telmisartan-loaded nanoparticles

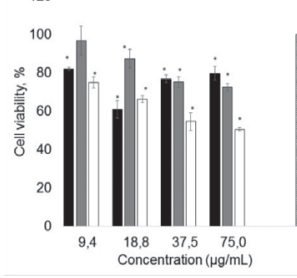

Figure 4. Cell viability of formulations after $48 \mathrm{~h}$ incubation. A: MCF-7 cells, B: MDA-MB-231 cells $(n=3$, mean \pm SE). *Indicates significantly different from control $(p<0.05)$

SE: Standard error, TLM-NP: Telmisartan-loaded nanoparticles

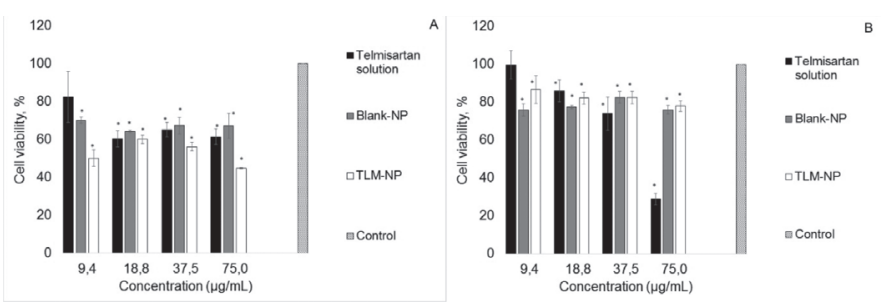

Figure 5. Cell viability of formulations after $72 \mathrm{~h}$ incubation. A: MCF-7 cells, B: MDA-MB-231 cells ( $n=3$, mean \pm SE). *Indicates significantly different from control $(p<0.05)$

SE: Standard error, TLM-NP: Telmisartan-loaded nanoparticles

it was especially pronounced at 48 and $72 \mathrm{~h}$ (Figures $4 \mathrm{~b}$ and $5 \mathrm{~b}$ ). Interestingly the TLM-NP formulation did not cause any significant loss of viability; $78 \%$ was the lowest viability, obtained with the TLM-NP formulation at $72 \mathrm{~h}$.

\section{DISCUSSION}

Novel strategies are being investigated for cancer therapy by repositioning various drugs that have different action mechanisms. Recently, these strategies have become extremely popular for the development of new potential cancer treatment modalities. Angiotensin II receptor antagonists are widely used for the treatment of hypertension and their anticancer activity was reported in various scientific papers.12,13 Several tumor cells were reported to express angiotensin II receptors: ${ }^{12-14}$ therefore, the anticancer effect of ARBs has been associated with inhibition of tumor angiogenesis. ${ }^{15-17}$ One of the ARBs, TLM, is generally used for treatment of cardiovascular diseases including hypertension and coronary artery diseases..$^{18}$ However, recent studies have drawn attention to the anticancer effect of TLM. As indicated in different studies, TLM showed antitumoral activities in various cancer types such as lung, prostate, ${ }^{19}$ and endometrium. ${ }^{2}$ Researchers have revealed that TLM has the potential to inhibit the proliferation of cancer cells through apoptosis by PPAR-gamma activation.13,20 PPARgamma activation by using TLM as a PPAR-gamma ligand may serve as an anticancer therapy model..$^{21}$

Due to properties mentioned above, TLM has the potential to be used in cancer therapy as a part of drug repositioning studies. However, TLM is a BCS class II model drug and has some limitations like poor solubility influencing its bioavailability. ${ }^{22}$ Therefore, to improve the solubility of TLM and to deliver it to the target site specifically, it is important to design an effective drug delivery system. TLM encapsulation within polymeric carriers is an alternative way to protect the drug from degradation, to ensure controlled release, and to increase bioavailability because of increased solubility.

Based on this idea, in the present study we prepared a polymeric nanoparticulate system by encapsulating TLM in PLA NPS by a modified emulsion solvent evaporation method to improve drug solubility. In addition, we aimed to investigate the anticancer efficiency of an antihypertensive drug nanoparticulate system as a potential, novel treatment modality for breast cancer. To the best of our knowledge this is the first study in which a novel drug delivery system was developed using PLA NPS to deliver the poorly soluble drug TLM as a model anticancer drug for breast cancer therapy.

In the present study, TLM-loaded and B-NP were prepared with biodegradable PLA polymer. As indicated in the literature, PLA is a biocompatible, biodegradable polymer that shows low toxicity and high mechanic strength, and so in the present study PLA polymer was chosen for these advantages. ${ }^{23,24}$ NPS were prepared by emulsion solvent evaporation, which involves emulsification of polymer solution and then evaporation of solvent, which precipitates the polymer as NPS. In order to obtain an optimized formulation, sonication time and polymer:drug ratio were evaluated in terms of particle size, PDI, EE, DLC. The particle size and PDI were measured by dynamic light scattering. Several parameters like sonication time and polymer:drug ratio highly affect the physicochemical properties of NPS, including particle size, EE, and drug loading ratio. Therefore, these parameters were studied to determine the optimum formulation. Different sonication times were tested to determine particle size as the first parameter and the results indicated that while the size of B-NP was in the range of 218-238 nm, the size of TLM-NP formulations was in the range of 273-333 nm. During the emulsification process sonication leads to dispersion of the organic phase into small nanodroplets, and so it is expected that by increasing sonication time more energy will be released and smaller droplets will be dispersed; consequently smaller NPS will be obtained. ${ }^{25}$ Increasing sonication time from $5 \mathrm{~min}$ to $10 \mathrm{~min}$ reduced particle size but nanoparticle size was higher when 20 min sonication was performed, compared to $10 \mathrm{~min}$ sonication. The decrease in particle size as the sonication 
time increases is expected, but several scientific papers report that there is a threshold value. ${ }^{26,27}$ After that threshold value is reached, increasing sonication time does not reduce particle size significantly. Furthermore, it should be noted that sonication is a very dynamic process; while sonication energy disrupts droplets into smaller droplets, some of the droplets may collide due to this energy and form larger droplets, which may explain why 20 min sonication caused a slight increase in particle size. The difference between the size of TLM-NP (formulations prepared with different sonication times and drug amounts) was statistically significant ( $p<0.05)$. As expected, encapsulating drug into PLA NPS caused an increase in particle size. The PDI results of the blank and TLM-NP were in the range of 0.1-0.3, indicating a narrow and homogeneous size distribution. As well as the sonication time, the second important parameter, different drug:polymer ratios, was tested. Increasing drug amount from 0.5 to $1 \mathrm{mg}$ in the formulation caused an increase in particle size. In contrast, by using $2 \mathrm{mg}$ of drug in the formulation, a smaller mean particle size was obtained. However, PDI was increased for this formulation, indicating that size distribution was not as narrow as in other formulations in which 0.5 and $1 \mathrm{mg}$ TLM were used. The effect of freeze-drying on the particle size of NPS was also investigated. Addition of trehalose as cryoprotectant to the NP suspension before the freeze-drying process resulted in decreased particle size generally. Similarly, Fonte et al. ${ }^{28}$ reported that the particle size of polymeric NPS lyophilized with trehalose was decreased and this may be related to adsorption of cryoprotectants on the nanoparticle surface and their particular behavior during freeze-drying. The negative zeta potential values of blank and TLM-NP decreased after lyophilization. This is attributed to the rearrangement of surfactants on the NP surface. Moreover, trehalose may mask the surface of NP due to hydrogen bonding between nanoparticle and cryoprotectant. ${ }^{29}$

EE was increased as higher drug amounts were used and the highest drug loading was achieved with 25:1 polymer:drug ratio. In vitro drug release experiments showed that TLM was released from the NPS slowly and in a sustained manner (40\% drug release at $24 \mathrm{~h}$ ). The drug's partitioning between polymer and aqueous release medium influences the release rate. ${ }^{30}$ Slow TLM (a hydrophobic drug) release from hydrophobic PLA NPS is explained by the solubility of drug in the polymer and its lower partitioning to the aqueous phase. Furthermore, coarse TLM powder dissolution (17.2\% in $24 \mathrm{~h}$ ) was significantly slower than the TLM-NP formulation ( $p<0.05$ ), indicating increased solubility of TLM. The release medium was $50 \mathrm{~mL}$ of PBS with $0.5 \%$ SLS $(\mathrm{pH}$ 7.4) and coarse TLM powder and TLM-NP equivalent to $0.15 \mathrm{mg}$ TLM were dispersed in PBS with 0.5\% SLS and were placed in a dialysis membrane. As solubility of TLM in PBS with $0.5 \%$ SLS ( $\mathrm{pH} 7.4$ ) was reported as $0.108 \pm 0.04 \mathrm{mg} / \mathrm{mL},{ }^{31}$ sink conditions were maintained during the experiment.
SEM images of NPS (Figure 2) show that they were clustered together during the drying process but individual spherical NPS were easily distinguished in images obtained at higher magnifications as expected.

The cell viability results indicate that although TLM solution decreased the cell viability of MCF-7 cells as the incubation time increased, the concentration viability relationship was erratic. TLM-NP decreased cell viability in a concentrationdependent manner to $45 \%$, even at the lowest concentrations at $72 \mathrm{~h}$ incubation. By using NPS, solubility can be increased and cellular uptake of drugs can be modified. The superior antiproliferative results of the TLM-NP formulation compared to TLM solution is thought to be linked to these properties of TLMNP formulations. TLM solution decreased the cell viability of MDA-MB-231 cells as the incubation time increased in a dosedependent manner. However, the TLM-NP formulation did not cause the same dramatic loss of viability. It is clear for MDAMB-231 cells that there should be a certain drug dose present in solution to see a significant loss of viability. Considering the slow drug release from TLM NPS, the reason for the high viability results obtained with them is attributed to the low amount of drug released. MCF-7 is an estrogen-dependent cell line and MDA-MB-231 is a triple negative cell line (cells that do not express estrogen receptor or progesterone receptor, and do not have HER-2/Neu amplification). It was reported that TLM induced the stimulation of collagen biosynthesis (which may influence cell growth and metabolism) in MCF7 cells cultured in the absence of estrogen and there was crosstalk between PPAR-gamma and estrogen receptor. However, collagen biosynthesis was not influenced by TLM in estrogen-independent MDA-MB-231 cells when cultured in the same conditions. ${ }^{32}$ As Kociecka et al. ${ }^{32}$ reported, the different responses of cells to TLM could be receptor related and need to be investigated further.

\section{Study limitations}

TLM NP formulations were prepared and their antiproliferative effect was investigated, but investigation of anticancer effect mechanisms was not within the scope of this study.

\section{CONCLUSION}

In our study TLM-loaded biodegradable PLA NPS were prepared and it was observed that sonication time and drug amount could impact NP size. It was demonstrated that sustained release TLM-NP inhibit proliferation of MCF-7 breast cancer cells better than TLM solution, indicating their potential use as an anticancer system. Further studies should be conducted to elucidate the anticancer mechanisms of TLM NPS on breast cancer cells.

\section{ACKNOWLEDGEMENTS}

The authors acknowledge İnönü University IBTAM for the SEM analysis. 
Conflicts of interest: No conflict of interest was declared by the authors. The authors alone are responsible for the content and writing of the paper.

\section{REFERENCES}

1. Li J, Chen L, Yu P, Liu B, Zhu J, Yang Y. Telmisartan exerts anti-tumor effects by activating peroxisome proliferator-activated receptor-gamma in human lung adenocarcinoma A549 cells. Molecules. 2014;19:28622876.

2. Koyama N, Nishida $\mathrm{Y}$, Ishii T, Yoshida T, Furukawa $\mathrm{Y}$, Narahara H. Telmisartan induces growth inhibition, DNA double-strand breaks and apoptosis in human endometrial cancer cells. PLoS One. 2014;9:e93050.

3. Matsuyama M, Funao K, Kuratsukuri K, Tanaka T, Kawahito Y, Sano H, Chargui J, Touraine JL, Yoshimura N, Yoshimura R. Telmisartan inhibits human urological cancer cell growth through early apoptosis. Exp Ther Med. 2010;1:301-306.

4. Kozako T, Soeda S, Yoshimitsu M, Arima N, Kuroki A, Hirata S, Tanaka H, Imakyure O, Tone N, Honda S-I, Soeda S. Angiotensin II type 1 receptor blocker telmisartan induces apoptosis and autophagy in adult T-cell leukemia cells. FEBS Open Bio. 2016;6:442-460.

5. Takahashi S, Uemura H, Seeni A, Tang M, Komiya M, Long N, Ishiguro $H$, Kubota $Y$, Shirai T. Therapeutic targeting of angiotensin II receptor type 1 to regulate androgen receptor in prostate cancer. Prostate. 2012;72:1559-1572.

6. Marasini N, Tran TH, Poudel BK, Cho HJ, Choi YK, Chi SC, Choi HG, Yong CS, Kim JO. Fabrication and evaluation of $\mathrm{pH}$-modulated solid dispersion for telmisartan by spray-drying technique. Int J Pharm. 2013;441:424432.

7. Zhong L, Zhu X, Luo X, Su W. Dissolution properties and physical characterization of telmisartan-chitosan solid dispersions prepared by mechanochemical activation. AAPS PharmSciTech. 2013;14:541-550.

8. Stangier J, Schmid J, Turck D, Switek H, Verhagen A, Peeters PA, van Marle SP, Tamminga WJ, Sollie FA, Jonkman JH. Absorption, metabolism, and excretion of intravenously and orally administered [14C] telmisartan in healthy volunteers. J Clin Pharmacol. 2000;40:1312-1322.

9. Patel J, Dhingani A, Garala K, Raval M, Sheth N. Design and development of solid nanoparticulate dosage forms of telmisartan for bioavailability enhancement by integration of experimental design and principal component analysis. Powder Technology. 2014;258:331-343.

10. Meredith PA. Optimal dosing characteristics of the angiotensin II receptor antagonist telmisartan. The American Journal of Cardiology. 1999;84:7-12

11. McCall RL, Sirianni RW. PLGA nanoparticles formed by single- or doubleemulsion with vitamin E-TPGS. J Vis Exp. 2013:51015.

12. Fujimoto Y, Sasaki T, Tsuchida A, Chayama K. Angiotensin II type 1 receptor expression in human pancreatic cancer and growth inhibition by angiotensin II type 1 receptor antagonist. FEBS Letters. 2001;495:197200.

13. Miyajima A, Kosaka T, Asano T, Asano T, Seta K, Kawai T, Hayakawa M. Angiotensin II type I antagonist prevents pulmonary metastasis of murine renal cancer by inhibiting tumor angiogenesis. Cancer Research. 2002;62:4176-4179.
14. Inwang ER, Puddefoot JR, Brown CL, Goode AW, Marsigliante S, Ho MM, Payne JG, Vinson GP. Angiotensin II type 1 receptor expression in human breast tissues. Br J Cancer. 1997;75:1279-1283.

15. Kosaka T, Miyajima A, Takayama E, Kikuchi E, Nakashima J, Ohigashi T, Asano T, Sakamoto M, Okita H, Murai M, Hayakawa M. Angiotensin II type 1 receptor antagonist as an angiogenic inhibitor in prostate cancer. Prostate. 2007:67:41-49.

16. Kosugi M, Miyajima A, Kikuchi E, Horiguchi Y, Murai M. Angiotensin II type 1 receptor antagonist candesartan as an angiogenic inhibitor in a xenograft model of bladder cancer. Clin Cancer Res. 2006;12:2888-2893.

17. Huang $\mathrm{W}, \mathrm{Wu} \mathrm{YL}$, Zhong J, Jiang FX, Tian XL, Yu LF. Angiotensin II type 1 receptor antagonist suppress angiogenesis and growth of gastric cancer xenografts. Dig Dis Sci. 2008;53:1206-1210.

18. Asmar R. Telmisartan in High Cardiovascular Risk Patients. European Cardiology Review. 2012;8:10-16.

19. Puri R, Kaur Bhatia R, Shankar Pandey R, Kumar Jain U, Katare OP, Madan J. Sigma-2 receptor ligand anchored telmisartan loaded nanostructured lipid particles augmented drug delivery, cytotoxicity, apoptosis and cellular uptake in prostate cancer cells. Drug Dev Ind Pharm. 2016:42:2020-2030.

20. Funao K, Matsuyama M, Kawahito Y, Sano H, Chargui J, Touraine JL, Nakatani T, Yoshimura R. Telmisartan as a peroxisome proliferatoractivated receptor-gamma ligand is a new target in the treatment of human renal cell carcinoma. Mol Med Rep. 2009;2:193-198.

21. Tyagi S, Gupta P, Saini AS, Kaushal C, Sharma S. The peroxisome proliferator-activated receptor: A family of nuclear receptors role in various diseases. J Adv Pharm Technol Res. 2011;2:236-240.

22. Isaac J, Ganguly S, Ghosh A. Co-milling of telmisartan with poly(vinyl alcohol)--An alkalinizer free green approach to ensure its bioavailability. Eur J Pharm Biopharm. 2016;101:43-52.

23. Mokale V, Naik J, Verma U, Yadava S. Preparation and Characterization of Biodegradable Glimepiride Loaded PLA Nanoparticles by o/w Solvent Evaporation Method Using High Pressure Homogenizer A Factorial Design Approach. SAJ Pharmacy and Pharmacology. 2014;1:1.

24. Feng C, Yuan X, Chu K, Zhang H, Ji W, Rui M. Preparation and optimization of poly (lactic acid) nanoparticles loaded with fisetin to improve anticancer therapy. Int J Biol Macromol. 2019;125:700-710.

25. Mainardes RM, Evangelista RC. PLGA nanoparticles containing praziquantel: effect of formulation variables on size distribution. Int $J$ Pharm. 2005;290:137-144.

26. Bilati U, Allémann E, Doelker E. Sonication parameters for the preparation of biodegradable nanocapsules of controlled size by the double emulsion method. Pharmaceutical development and technology. 2003;8:1-9.

27. Cun D, Foged C, Yang M, Frøkjær S, Nielsen HM. Preparation and characterization of poly (DL-lactide-co-glycolide) nanoparticles for siRNA delivery. International journal of pharmaceutics. 2010;390:70-75.

28. Fonte P, Soares S, Costa A, Andrade JC, Seabra V, Reis S, Sarmento B. Effect of cryoprotectants on the porosity and stability of insulin-loaded PLGA nanoparticles after freeze-drying. Biomatter. 2012;2:329-339.

29. De Chasteigner S, Cavé G, Fessi H, Devissaguet JP, Puisieux F. Freezedrying of itraconazole-loaded nanosphere suspensions: a feasibility study. Drug Development Research. 1996;38:116-124. 
30. Panyam J, Williams D, Dash A, Leslie-Pelecky D, Labhasetwar V. Solidstate solubility influences encapsulation and release of hydrophobic drugs from PLGA/PLA nanoparticles. J Pharm Sci. 2004;93:1804-1814.

31. Chella N, Narra N, Rama Rao T. Preparation and characterization of liquisolid compacts for improved dissolution of telmisartan. Journal of drug delivery. 2014;2014:692793.
32. Kociecka B., Surazynski A., Miltyk W., Palka J. The effect of Telmisartan on collagen biosynthesis depends on the status of estrogen activation in breast cancer cells. Eur J Pharmacol. 2010;628:51-56. 